The Industrial Need of Technically Trained Men-IX The Possibilities in Iron and Steel Making

By S. T. Wellman

[Mr. S.T. Wellman, the author of the following article, has had a large part in the development of the iron and steel industry from small proportions just after the civil war to the enormous production of to-day. He is the inventor of a tilting open hearth furnace and of the charging machine which made the open hearth furnace practicable. Mr. Wellman has been general superintendent and engineer of the Otis Iron and Steeb Company and president of the Wellman Seaver Morgan Company. He is past president of the American Society of Mechanical Engineers and of the Cleveland Engineering Society. He is a member of the American Institute of Mining Engineers, the American Iron and Steel Institute and of the British Iron and Steel Institute.-EDitor.]

S the profession of "Iron and Steel |tails of the business practically, but makMaking" a good one to follow? This is who are trying to make up their minds as to their life's work.

The answer will depend very largely upon the man. Many would not like the business at all, and some, as I have seen them do, would turn and leave at the first sight of what the work and conditions are, saying: "None of that for me."

One young man that I remember many years ago, at his first sight of a Bessemer converter timing up, sending as it always does a shower of fire across the building, turned and fied headlong and neve stepped inside the works again.

To me the iron business is the most fascinating in the world. All of the processes are interesting. New problems, mechanical and metallurgical, are constantly coming up to be solved.

There is plenty of room in the iron business for workers, but none for drones. The young man who adopts it for his life's work must have in the first place a good physique; he must be strong and healthy in mind and bedy, not. afraid of work or dirty hands or rough clothes. He must expect at times to make long hours, when he is learning the business, and at times he will have a great deal of night work.

A college or technical sehool education desirable. The young man who starts in the business without such an education, of self education at home if he wishes tained his coveted degree, he must not ever to reach the top of the ladder. That any works, or even a department of it. it is possible to do this is shown by the If he has sense, he will know that he is careers of many of the brightest and most only learning the theory of things, but the careers of many of the brightest and most only learning the theory of things, but the
successful men in the business. Night hard practical part he has yet to learn. and correspondence schools are open to the A man who expects to be a leader in any poor working boy who has the ambition business should know every detail. He to rise, and who is bound to learn all should be able to take any workman's that is worth learning in his chosen pro- place for a short time. I don't mean to fession. The very fact that he has to say that he should work at every branch work hard in the face of all kinds of dif- of the trade long enough to become a firstficulties to learn what he is after, is the class workman, but he should work at it best kind of a beginning of a training for long enough to get a thorough, practical what is to come.

Many times, when asking professors at this and does come to a position of respontechnical schools and colleges to send me sibility, not understanding the details in graduates for different positions, I said a practical way, the workmen will very to them: "Everything else being equal, soon find it out and they will be sure to I would rather have a poor boy who has take advantage of his ignorance.

worked his way through college than a Of course, if a young man goes into the rich man's son who doesn't know the value iron business and expects to earn a living of a dollar, and whose chief reason for with his hands and muscles only, and to being at college is to have a good time." be merely a workman, skilled or unskilled,

The common opinion is that the poor book knowledge will not help him very boy is the one who is handicapped in mak- much. He might as well stop with a coming the race for real success in life. I am mon school education. But if he wants not sure but that this is wrong, and that to make his brains and not his hands do it is very possible that the rich man's son, the work, he must get all the help possible surrounded by every luxury, who lives in from the best that books can teach. Of a beautiful home, with a doting mother watching over him, who never learns or knows the value of money, is the one to be pitied, and is really the boy who is handicapped.

The best assistant that I ever had was a young man who was the son of a barber. He graduated at the high school, after which he went to work in the office of an iron works of his native town. In a year or two he had saved five hundred dollars. With this and the addition of one thousand dollars which his employer loaned him, he went to Germany, where he stayed four years. This amount of money paid all his expenses. Of course, this was possible only by the exercise of the most rigid economy. He entered the University of Berlin, where he graduated, taking the highest honors that any American had taken up to that time. He spent all of iron and steel, and nowhere is it carried his vacations in various iron works as a on in such magnificent scale as in this leasner, thus not.onls gettlog at the do country in which we live.

Workmen who have a superintendent under whom they have learned their trade are more easily managed than if they had brought their trade with them, and its details are in any part a secret from the anagement. If they know that the superas they do themselves, they will know that, having taught them, he can teach others. trikes are not likely to happen where the management is in such hands. To my mind, the business of the ironmoster is the mosteresting of any of work is full of the . Every part of the detail, from the taking of

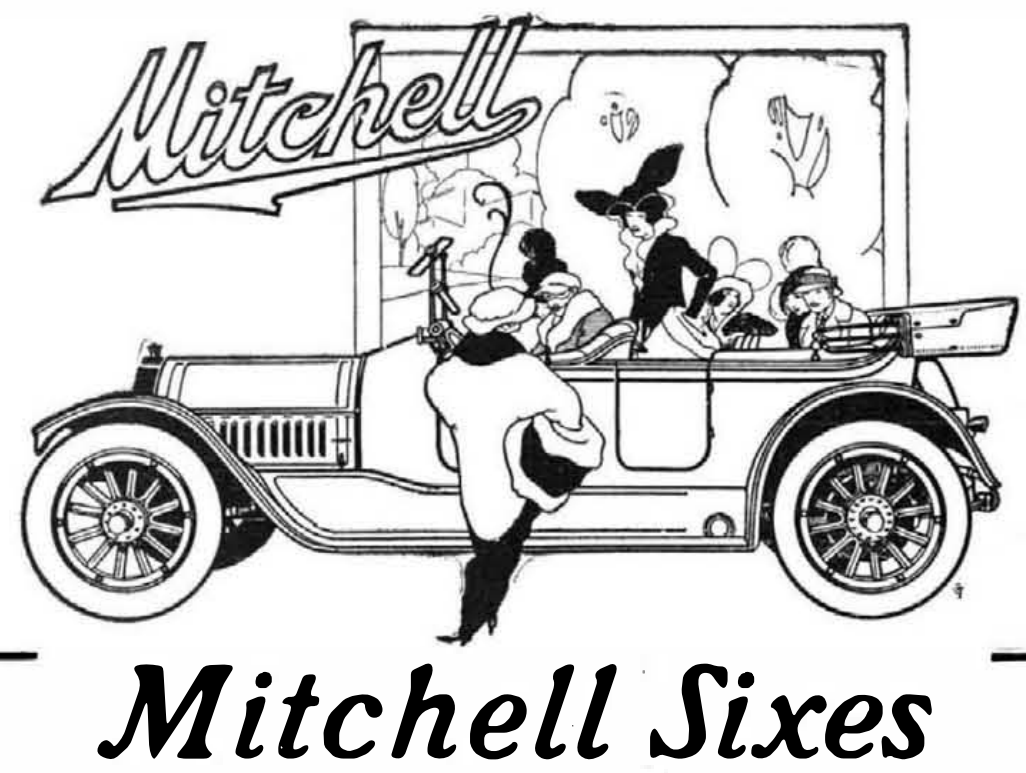

Products of Long Experience

This company has been building popular priced sixes longer than any other concern in this country. Hence the sixes we offer are the product of many years of experience, and in no sense experiments.

The Mitchell Little Six which was known as the "Baby Six" in 1912, is, in our opinion, the profoundly logical investment
in the automobile market. It is not only the sensible compromise between big and little power and passenger capacity, but it has everything that any high. priced car can offer you.

It has quality that insures long life. It has the style of beauty that the exacting mind demands. It has as much speed and power as any person can desire. It will hold its place in any company and look and details thereof sterling in character. The price, $\$ 1,895$, brings this smart car to you ready for instant use. There is nothing left for you to buy-no extrasno appurtenances.

The Mitchell Big Six is the biggest and best car at the price that has ever been produced. It is built along the same lines as
the Little Six save that it has 144-inch wheel base, somewhat larger tires, greater the Little Six save that it has 144-inch wheel base, somewhat larger tires, greater
passenger capacity. Yet the quality of the two are identical. The equipment is precisely the same-the outward beauty similar. For a big family car the Big Six $\$ 4,000$. The price of the Mitchell Big Six is only $\$ 2,350$.

The Mitchell Four is intended for those who feel that they cannot afford either of the Sixes. It is the only four-cylinder
car we make. We build it to meet the demand of those persons who still like car we make. We build it to meet the demand of those persons who still like a.four-cylinder car of class at a popular price. It has the same equipment as the
other two cars and sells for $\$ 1,595$. We want you to look this car over minutely other two cars and sells for $\$ 1,595$. We want you to look this car over minutely
and then ask yourself if there is a four-cylinder car at anywhere near the price that and then ask yourself if there is a four-cy
can compare with this one in any detail.

Here is the Equipment for all the Mitchell Models Which is Included in the Price as Given

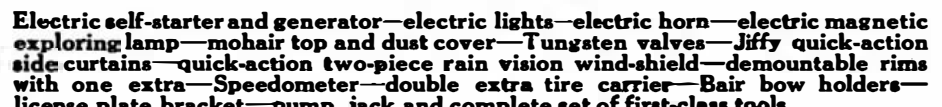

Specifications of the Three Great Mitchell Models:
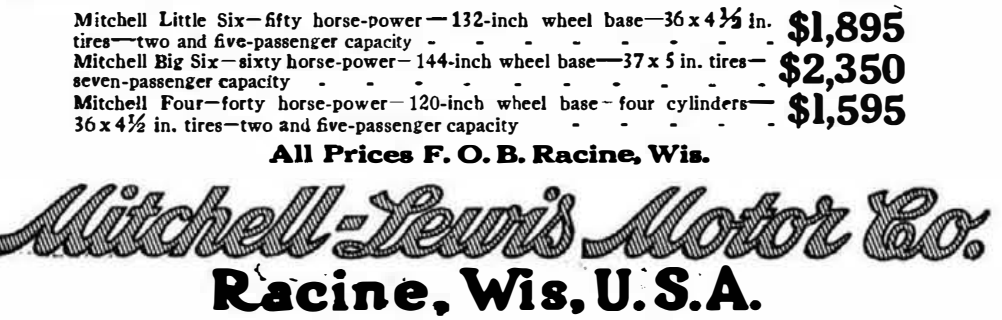

Eighty Years of Faithful Service to the American Public

\section{Wireless Telegraphy and Telephony}

SIMPLY EXPLAINED

70 pages, 156 Illustrations. By ALFRED P. MORGAN. Price \$1.00 Postpaid.

The simplest, latest and most comprehensive popular work published
on wireless, for the wireless operator, amateur or professional.

This is undoubtedly one of the most comprehensive treatises on the subject, and a close study of its pages will enable one to master all the details of the wireless transmission of messages. - The author has filled a long-felt want and has succeeded in furnishing a lucid, comprehensible explanation in simple language of the theory and practice of wireless telegraphy and telephony.

The book treats the subject from an entirely new standpoint. It is well illustrated by over one hundred and fifty interesting photographs and drawings. All diagrams have been made in perspective, showing the instruments as they actually appear in practice. The drawings are carefully keyed and labeled. Many of the photographs are accompanied by phantom drawings which reveal the name and purpose of each part.

$$
\begin{aligned}
& \text { A book the wiveleas experimenter cannot afford to be without. It enables } \\
& \text { one to derion and contrat apperatus. Also oaluable to the lavmar }
\end{aligned}
$$

MUNN \& COMPANY, Inc.

391 Broadway, New Yort Cits 